\title{
PENDIDIKAN DAN PAHAM KEAGAMAAN PESANTREN NURUSSALAM CIAMIS
}

\section{EDUCATION AND EDUCATIONAL THOUGHTS OF PESANTREN NURUSSALAM CIAMIS}

\author{
Husen Hasan Basri \\ Puslitbang Pendidikan Agama dan Keagamaan \\ Badan Litbang dan Diklat Kemenag RI \\ Email: hhasanbasri@yahoo.com
}

\begin{abstract}
Pesantren Nurussalam Ciamis is often associated with the movement of Abu Bakar Ba'asyir who was caught in Banjar in August 2010. Even in 2013, this Islamic boarding school is linked again with the arrest of terrorist Anton who is allegedly an alumnus of Nurussalam Islamic Boarding School. After the bombing of Thamrin on January 14, 2016, Nurussalam Islamic Boarding School is indicated by the National Agency for Combating Terrorism (BNPT) as one of radical Islamic boarding schools. The question is whether Nurussalam Islamic Boarding School is really a source of radicalism. To answer that question, we see two aspects of Pesantren Nurussalam namely its education method and religious understanding. Through qualitative method, it is found that Pesantren Nurussalam education system generally refers to the national education system plus Islamic education system adopted from Gontor and Ngruki models. The educational system built is not separated from the religious understanding of the founders and managers who understand salafi, more precisely salafi puris cooperationis. Although it adheres to Salafi, Pesantren Nurussalam refuses to be categorized as radical Islamic boarding school.
\end{abstract}

Keywords: Education, Religiousism, Salafi

\begin{abstract}
Abstrak
Pesantren Nurussalam Ciamis sering dikaitkan dengan gerakan Abu Bakar Ba'asyir yang tertangkap di Banjar Ciamis Agustus tahun 2010. Bahkan pada 2013, pesantren ini dikaitkan lagi dengan penangkapan teroris Anton yang diduga alumni Pesantren Nurussalam. Pasca peristiwa bom Thamrin 14 Januari 2016, Pesantren Nurussalam diindikasikan oleh Badan Nasional Penanggulangan Terorisme (BNPT) sebagai salah satu pesantren radikal. Apakah Pesantren Nurussalam sebagai sumber radikal. Untuk itu dilihat dua aspek dari Pesantren Nurussalam, yaitu bagaimana pendidikan dan paham keagamaan Pesantren Nurussalam. Melalui metode kualitatif ditemukan bahwa sistem pendidikan pesantren Nurussalam secara umum mengacu kepada sistem pendidikan nasional ditambah sistem pendidikan kepesantrenan yang diadopsi dari model Gontor dan model Ngruki. Sistem pendidikan yang dibangun tersebut tidak lepas dari paham keagamaan para pendiri dan pengelolanya yang berpaham salafi, lebih tepatnya salafi puris cooperationis. Meski berpaham keagamaaan salafi, pihak Pesantren Nurussalam menolak untuk dikategorikan pesantren radikal.
\end{abstract}

Kata Kunci:Pendidikan, Paham Keagamaan, Salafi 


\section{PENDAHULUAN}

Pesantren Nurussalam merupakan salah satu dari 541 pesantren di Ciamis. ${ }^{1}$ Pesantren ini didirikan pada 1 Juli tahun 1988 atas cita-cita 2 (dua) orang ustadz Abdul Hadi dan ustadz Wahyudin, yang keduanya alumni pesantren Gontor, dengan dukungan masyarakat. Pada saat itu, ustadz Abdul Hadi memimpin pesantren, dan ustadz Wahyudin mengabdikan diri di Pesantren Al-Mukmin Ngruki Solo. Karena alumni Gontor, ustadz Abdul Hadi menjalankan aktivitas kependidikannya sedikit banyak mengadopsi model Gontor, seperti sistem Kulliyatul Muallimin Islam (KMI). ${ }^{2}$

Sepeninggalnya ustadz Abdul Hadi 6 September tahun 2010, kepengurusan pesantren diserahkan kepada ustadz Wahyudin. Selain di Pesantren Nurussalam, ustadz Wahyudin juga mudir di Pesantren Al-Mukmin Ngruki Solo. Meski banyak dihabiskan waktu sehari-harinya di Pesantren Al-Mukmin Ngruki Solo, ustadz Wahyudin tetap mengontrol aktivitas kepesantrenan.Dibawahkepemimpinannya, orientasi pendidikan Pesantren Nurussalam dikombinasikan antara model kependidikan Gontor dan model kependidikan Ngruki.

${ }^{1}$ Berdasarkan data dari Kemenag Kabupaten Ciamis Tahun 2015-2016. Dari jumlah 541 pesantren, dilihat dari konsentrasi pesantren di bidang agama sebagai berikut: 89,3 \% fiqih/ushul fikih, 6,5 \% akidah/tauhid, 1,3\% tahfidzul quran, 0,4 \% tafsir, 0,4 $\%$ nahwu/sharaf, masing-masing 0,2 \% tasawuf, ilmu falak, dan bahasa Arab. Konsentrasi bidang agama lainnya 0,2 \%, tidak ada konsentrasi 0,6 \%, dan 0,9\% pesantren tidak menjawab.

2 Tentang Sistem KMI ini lihat, KH Abdullah Syukri Zarkasyi. 2005. Gontor dan Pembaharuan Pendidikan Islam, Jakarta, PT Raja Grafindo Persada. Lihat juga KH Abdullah Syukri Zarkasyi. 2005. Manajemen Pesantren: Pengalaman Pondok Modern Gontor, Jawa Timur, Trimurti Press
Namun dalam beberapa kesempatan, pihak Pesantren Nurussalam menyatakan bahwa Pesantren Nurussalam adalah pesantren independen. ${ }^{3}$

Keberadaan pesantren independen bukan sesuatu yang baru. Pesantren Modern Darussalam Gontor yang didirikan pada 1926 merupakan sebuah contoh sekaligus salah satu akar tumbuhnya pesantrenpesantren independen. Ciri utama pondok modern adalah sifat independennya terhadap organisasi muslim seperti NU, Muhammadiyah, Persis dan sebagainya. Ciri-ciri lainnya dari pondok modern adalah Kulliyat al-Muallimin al-Islamiyah (KMI), penekanan kepada pelajaran bahasa Arab dan Inggris, dan tidak menjadikan kitab kuning sebagai buku teks, tetapi menggunakan buku-buku teks keislaman yang ditulis pada masa modern. Sebagai model, pondok modern mengalami disseminasi ke wilayahwilayah di Indonesia. Beberapa model pondok modern adalah Pondok Modern Pabelan di Magelang, Pondok Modern Darunnajah di Jakarta, dan Pondok Modern Darul Qalam Gintung Tangerang. ${ }^{4}$

${ }^{3}$ Wawancara dengan wakil mudir pesantren, Maksum Abdurahman, dan sekretaris pesantren, Yoyo Yahya, di kampus Pesantren Nurussalam, 8 Pebruari 2016.

${ }^{4}$ Menurut Subhan, terdapat beberapa varian pesantren yang memiliki akar pada pondok modern, terutama dari perspektif ideologi keagamaan seperti Pesantren al-Mukmin Ngruki, Pesantren Al-Zaytun Indramayu, dan Pesantren Hidayatullah Balikpapan. Ketiga pesantren tersebut didirikan oleh orangorang yang pernah mengenyam pendidikan di Pondok Modern Darussalam Gontor, yaitu: Abu Bakar Ba'asyir, AS Panji Gumilang, dan Abdullah Said. Lihat Arief Subhan, 2012, Lembaga Pendidikan Islam Indonesia Abad ke-20: Pergumulan antara Modernisasi dan Identitas. Jakarta, Kencana, h. 288-289. 
Penelitian Noorhaidi sebagaimana dicatat oleh Subhan memberikan sebuah kenyataan baru tentang perkembangan pesantren independen di Indonesia. Selain independen, ideologi salafi menjadi ciri yang menonjol dari pesantren tersebut. Salah satu "pesantren salafi"-demikian pesantren yang memiliki ciri independen dan ideologi salafi itu disebut-adalah Pesanten Ihya alSunnah yang berlokasi di Degolan Kaliurang Yogyakarta. ${ }^{5}$

Dalam perkembangannya, Pesantren Nurussalam dikaitkan dengan gerakan Abu Bakar Ba'asyir yang tertangkap di Banjar Ciamis Agustus tahun 2010.6 Bahkan pada 2013, pesantren ini dikaitkan lagi dengan penangkapan teroris Anton yang diduga alumni Pesantren Nurussalam. Tetapi, pihak pesantren menyanggahnya bahwa Anton bukan alumni Pesantren Nurussalam. ${ }^{7}$

Pasca peristiwa bom Thamrin 14 Januari 2016 memunculkan adanya pelaku yang diduga memiliki paham dan jaringan dengan kelompok radikal baik di Indonesia seperti Darul Islam (DI, Jamaah Islamiyah (JI), Majlis Mujahidin Indonesia (MMI), Jamaah Aanshorut Tauhid (JAT), Mujahidin Indonesia Barat (MIB) maupun jaringan internasional seperti ISIS dan Jabhat Al- Nusra, suatu cabang Al-Qaeda di Suriah. Kurang lebih setengah bulan kemudian, Badan Nasional Penanggulangan Terorisme (BNPT) meliris 19 pondok pesantren (sebenarnya 20 pesantren karena ada 2 nama lembaga yang disatukan) yang terindikasi mengajarkan

${ }^{5}$ Ibid., h. 290.

${ }^{6}$ Lihat Tempo, Selasa 10 Agustus 2010.

${ }^{7}$ Lihat Kompas, Kamis 2 Januari 2014. doktrin bermuatan radikalisme dari hasil proses profiling timnya di lapangan. ${ }^{8}$

Pesantren-pesantren tersebut terlihat mendukung dan menyemaikan ajaran radikalisme di Indonesia. Menurut kepala BNPT, pondok pesantren yang dianggap radikal masuk dalam pantauan karena sejumlah tersangka teroris yang sudah ditangkap berasal dari pondok pesantren tersebut. Menurutnya ada beberapa alumni yang menjadi tersangka teroris, tak sedikit juga mereka para tersangka yang mengajar di sana. ${ }^{9}$ Pesantren Nurussalam diindikasikan oleh BNPT sebagai salah satu pesantren radikal karena terkait dengan Darul Islam (DI), Jamaah Islamiyah (JI), Majlis Mujahidin Indonesia (MMI), Jamaah Ansharuttauhid (JAT) dan Mujahidin Indonesia Barat. ${ }^{10}$

Menteri Agama mempertanyakan data BNPT soal pesantren radikal. Menurutnya, pesantren yang terindikasi menyebarkan radikalisme hanya bersifat kasuistik. Jika ada satu-dua pesantren yang mengantarkan faham radikalisme perlu dipertanyakan apa benar itu pondok pesantren atau hanya mengatasnamakan pesantren. Bahkan wakil presiden, Jusuf Kalla, mempertanyakan kriteria radikalisme yang disematkan BNPT. ${ }^{11}$

Pemberitaan media tentang adanya dugaan keterkaitan Pesantren Nurussalam

${ }^{8}$ Lihat Daftar Pesantren Yang Terindikasi Berafiliasi dengan kelompok Radikal Hasil Profiling Badan Nasional Penanggulangan Terorisme (BNPT) Tahun 2014. Daftar tersebut diberikan BNPT kepada Puslitbang Pendidikan Agama dan Keagamaan pada Pebruari 2016.

${ }^{9}$ Republika, 3/2/2016.

${ }^{10}$ Lihat Daftar Pesantren Yang Terindikasi Berafiliasi dengan kelompok Radikal Hasil Profiling Tahun 2014.

${ }^{11}$ Republika, 4/2/2016. 
dengan para pelaku kekerasan, dan tuduhan BNPT terhadap pesantren Nurussalam yang terindikasi radikal, memunculkan pertanyaan-pertanyaan. Mengapa Pesantren Nurussalam diduga oleh Media memiliki keterkaitan dengan para pelaku kekerasan, dan dituduh BNPT terindikasi radikal?. Nurussalam sejak tahun 1988-2016 sebagai lembaga pesantren yang aktivitas kesehariannya bergerak dalam bidang pendidikan dan sudah menghasilkan para alumni. Pesantren Nurussalam menyelenggarakan pendidikan MTs dan MA. Pesantren Nurussalam mengajarkan pengetahuan agama Islam yang dipraktekkan dalam kehidupan keseharian di Pesantren. Para alumninya diharapkan menjadi kader muslim yang mampu mengamalkan ajaran-ajaran Islam baik untuk dirinya maupun orang lain. Pesantren Nurussalam melakukan interaksi dengan berbagai pihak baik Pemerintah seperti Kementerian Agama maupun pihak swasta.

Berdasarkan latar belakang diatas, permasalahan penelitian adalah bagaimana pendidikan dan paham keagamaan Pesantren Nurussalam Ciamis Jawa Barat. Penelitian ini bertujuan untuk memperoleh data dan informasi yang lengkap tentang pendidikan dan paham keagamaan pesantren Nurussalam Ciamis Jawa Barat, sebagai bahan masukan bagi pemerintah guna perumusan kebijakan dalam melakukan pembinaan pesantren pada umumnya dan pesantren Nurussalam pada khususnya. Selain itu informasi juga berguna untuk pengetahuan masyarakat tentang berbagai persoalan pendidikan di pesantren Nurussalam Ciamis.

\section{METODOLOGI PENELITIAN}

Penelitian menggunakan pendekatan kualitatif fenomenologis. Pengumpulan data (studi pendahuluan) dilakukan pada 7-11 Februari 2016. Selanjutnya dilakukan pengumpulan data yang kedua pada 28 Maret-6 April 2016. Sumber data didapatkan melalui: wawancara kepada pengasuh, ustadz, Kementerian Agama, pejabat daerah, MUI, masyarakat; observasi di pesantren; dan studi dokumentasi. Data yang dipaparkan berikut ini merupakan data dan informasi dari hasil fact finding (pengumpulan data yang pertama) dan pengumpulan data lanjutan terhadap Pesantren Nurussalam. Karena itu proses analisa data dilakukan sebelum, selama, dan setelah penelitian sebagaimana paradigma sebuah penelitian kualitatif. Dalam proses analisa data tersebut digunakan alat analisa pendidikan dan gerakan keagamaan. Hasil analisa data dalam bentuk "klasifikasi" dan "kategorisasi" itulah yang dipaparkan dalam hasil dan pembahasan berikut.

\section{HASIL DAN PEMBAHASAN}

\section{Pendidikan Nurussalam: Dari Model Gontor, Model Ngruki Sampai Model Kementerian Agama}

Pondok Modern Darussalam Gontor (PMDG) didirikan pada 20 September 1926 oleh tiga bersaudara, yaitu: KH Ahmad Sahal (1901-1977), KH Zainuddin Fannani (19051967), dan KH Imam Zarkasyi (1910-1985). Kepemimpinan PMDG generasi kedua adalah KH Shoiman Lukmanul Hakim, KH Abdullah Syukri Zarkasyi, dan KH Hasan Abdullah Sahal. Pada 1999, KH Shoiman Lukmanul Hakim wafat, Badan Wakaf mengangkat $\mathrm{KH}$ Imam Badri sebagai pimpinan pondok yang 
baru bersama -sama dengan KH Abdullah Syukri Zarkasyi, dan KH Hasan Abdullah Sahal. ${ }^{12}$

Sistem pendidikan PMDG menggunkan Kulliyat al-Mu'alimin al-Islamiyah (KMISekolah Pendidikan Guru Islam). Sistem ini diperkenalkan sebagai pengganti sistem Tarbiyat al-Atfal dan Sullam al-Muta'allimin. PMDG berbentuk Badan Wakaf yang berarti pondok menjadi milik institusi bukan milik pribadi. Setelah seperempat KMI berdiri, dibukalah Institut Studi Islam Darussalam (ISID). Pada era kepemimpinan generasi kedua, PMDG mendirikan Pusat Latihan Manajemen dan Pengembangan Masyarakat (PLMPM), membuka pondok-pondok cabang Gontor, kampus terpadu ISID, mengembangkan bidang ekonomi untuk menunjang kemandirian pondok, dan ijazah KMI memperoleh pengakuan persamaan dari Kementerian Agama (tahun 1998) dan Kementerian Pendidikan Nasional (tahun 2000). ${ }^{13}$

Nilai-nilai dasar yang ditanamkan PMDG tertuang dalam Panca Jiwa Pesantren, yaitu: jiwa keikhlasan, jiwa kesederhanaan, jiwa berdikari, jiwa ukhuwah diniyyah, dan jiwa bebas. Nilai-nilai PMDG juga tertuang dalam moto: berbudi tinggi, berbadan sehat, berpengetahuan luas, dan berfikiran bebas. PMDG memiliki falsafah yang terdiri dari motto kelembagaan, motto kependidikan, dan motto pembelajaran. ${ }^{14}$

12 Lihat KH Abdullah Syukri Zarkasyi, 2005, Gontor \& Pembaharuan Pendidikan Pesantren. Jakarta, Grafindo Persada, h. 87-88

${ }^{13}$ Ibid., h. 93-99

14 Falsafah dan motto kelembagaan adalah: (1) pondok berdiri di atas dan untuk semua golongan, (2) pondok adalah lapangan perjuangan bukan tempat mencari penghidupan, dan (3) pondok itu milik umat bukan milik kyai. Falsafah dan motto kependidikan
PMDG dengan pembaharuan pendidikannya dari mulai kelembagaan, organisasi, manajemen, kurikulum, dan metode pembelajaran, sering disebut oleh masyarakat dan KH Syukri Zarkasi sebagai "pesantren model" yaitu model PMDG. Model pendidikan yang diterapkan di PMDG makin mendapat tempat di kalangan masyarakat. Hal itu terbukti dari banyaknya pesantren yang didirikan mengikuti model tersebut. Sebagaimana diakui oleh KH Syukri Zarkasyi, selain adopsi yang dilakukan pesantren yang didirikan alumni PMDG, sistem pendidikan model Gontor juga banyak mewarnai pesantren-pesantren

adalah: (1) apa yang dilihat, didengar, dirasakan, dan dialami santri sehari-hari harus mengandung unsur pendidikan, (2) berbudi tinggi, berbadan sehat, berpengetahuan luas, dan berpikiran bebas, (3) jadilah ulama yang intelek, bukan intelek yang tahu agama, (4) hidup sekali, hiduplah berarti, (5) berjasalah tetapi jangan minta jasa, (6) sebesar keinsafanmu, sebesar itu pula keuntunganmu,(7) mau dipimpin dan siap memimpin, patah tumbuh hilang berganti, (8) berani hidup tak takut mati, takut mati jangan hidup, takut hidup mati saja, (9) seluruh mata pelajaran harus mengandung akhlak, (10) In uridu illa al-islah, (11) sebaik-baik manusia ialah yang paling bermanfaat untuk sesamanya; (12) pendidikan itu by doing, bukan by lip, (13) perjuangan itu memerlukan pengorbanan: bondo, bahu, pikir, lek perlu sak nyawane, (14) I'malu fawqa ma 'amilu, (15) hanya orang penting yang tahu kepentingan, dan hanya pejuang yang tahu arti perjuangan, dan (16) sederhana tidak berarti miskin. Adapun Falsafah dan Motto Pembelajaran adalah: (1) metode lebih penting daripada materi, guru lebih penting daripada metode, dan jiwa guru lebih penting daripada guru itu sendiri (al-tariqah ahammu min al-maddah, al-mudarrisu ahammu min altariqah, wa ruh al-mudarrisi ahammu min al-mudarris), (2) pondok membekali kail, tidak memberi ikan, (3) ujian untuk belajar, bukan belajar untuk ujian, (4) ilmu bukan untuk ilmu, tetapi ilmu untuk amal dan ibadah; dan (5) pelajaran di pondok, agama 100\% dan umum 100\%. Lihat KH Abdullah Syukri Zarkasyi, h. 101-105. 
tradisional di Indonesia, baik dari segi sistem, kurikulum maupun pola pengajaran.

Salah satu pesantren yang didirikan alumni PMDG adalah Pesantren Nurussalam. Sejarah Pesantren Nurussalam didirikan oleh Abdul Hadi dan Wahyudin yang keduanya alumni PMDG tahun 1980-an. Seberapa besar Pesantren Nurussalam mengadopsi pendidikan model Gontor.

Penulis mulai dari sisi kelembagaan dan aspek organisasi. Kelembagaan Pesantren Nurussalam berada di bawah yayasan Nurussalam. Hal ini berbeda dengan PMDG yang berstatus Badan Wakaf. Kepemilikan aset Pesantren Nurussalam berada di tangan para pengurus yayasan Nurussalam. Mereka yang memahami dan merasa bertanggung jawab terhadap jalannya Pesantren Nurussalam. Tetapi sistem kelembagaan pesantren ini memiliki kelemahan. Diantaranya adalah bahwa tidak semua keluarga pendiri dapat mengerti dan memahami pondok dengan segala persoalannya sehingga sangat terbuka kemungkinan bagi kepentingan dan persoalan keluarga akan muncul dan berubah menjadi kepentingan dan persoalan pondok. Misalnya, kasus perubahan "Yayasan Nurussalam" menjadi "Yayasan Nurrussalam" yang ditambah huruf "r" nya dua. Hal ini menjadi persoalan karena salah satu pihak ahli waris keluarga ustadz Abdul Hadi mempertanyakan perubahan nama yayasan tersebut. Meski menurut penuturan Andi, salah seorang ahli waris Ustad Wahyudi, bahwa dirinya merasa keberatan dengan perubahan nama tersebut, ${ }^{15}$ tetapi

15 Wawancara dengan Andi, putra almarhum ustadz Abdul Hadi, di Kantor Kementrian Agama Kabupaten Ciamis pada 24 Maret 2016. penulis lebih melihat keberatannya itu karena Andi tidak dimasukan dalam struktur kepengurusun yayasan yang baru.

Berbeda dengan kelembagaan Badan Wakaf seperti PMDG yang kepemilikan aset pesantren itu menjadi milik institusi umat. Konsekuensi dari kelembagaan Badan Wakaf adalah ahli waris pendiri tidak mempunyai hak untuk mewaris harta dan aset-aset materi pondok. Karena itu kelangsungan hidup pondok bukan hanya menjadi tangung jawab keluarga, tetapi telah menjadi tanggung jawab semua umat Islam.

Sebagai alumni PMDG, Ustadz Abdul Hadi pada awalnya mengadopsi sistem Kulliyat al-Mu'allimin al-Islamiyah (KMI) model Gontor. Seperti di Gontor, Pesantren Nurussalam menyelenggarakan kegiatan belajar-mengajar pada tingkat menengah dengan masa belajar 6 tahun (bagi lulusan SD) dan 4 tahun (bagi lulusan SLTP/ SLTA/PT). Seperti PMDG juga, Pesantren Nurussalam memiliki semacam lembaga "pengasuhan santri" yang mendidik dan membina langsung seluruh kegiatan ekstrakulikuler santri KMI yang mencakup kegiatan-kegiatan yang diselengarakan oleh Organisasi Pelajar Pondok Nurussalam. Pesantren Nurussalam juga menangani kegiatan-kegiatan alumni yang tersebar di Indonesia yang bernama IKSAN (Ikatan Alumni Nurussalam). Organisasi ini melakukan kegiatan sosial, pendidikan, keagamaan ataupun kekeluargaan. Di PMDG, organisasi ini bernama Ikatan Keluarga Pondok Modern (IKPM).

Melalui sistem KMI, Pesantren Nurussalam mengadopsi model kurikulum di Gontor. Pesantren Nurussalam mengintegrasikan ilmu agama (revealed 
knowledge) dan ilmu kawniyah (acquired knowledge) sehingga seperti diakui oleh Ustadz Yahya, pengajaran ilmu kawniyah tidak terlepas dari dasar dan ilmu agam, dan sebaliknya pengajaran ilmu-ilmu agama dikembangkan dengan perkembangan keilmuan umum. Sebelum ada sistem madrasah model Kementrian Agama, di Pesantren Nurussalam pada masa awal-awal berdiri terbagi kepada dua organisasi untuk melaksanakan kurikulum, yaitu: lembaga pengasuhan santri dan lembaga KMI. Lembaga pengasuhan santri untuk kegiatankegiatan ekstrakulikuler seperti kegiatan ibadah amaliah, latihan pidato, latihan dan praktek berorganisasi. Sedangkan lembaga KMI bertanggung untuk kegiatan intrakulikuler seperti menentukan program, jam belajar, dan muatan isi kurikulum. Praktek ini persis seperti di PMDG.

Ustadz Abdul Hadi menerapkan pola pengajaran model Gontor yaitu bermottokan: metode lebih penting daripada materi, guru lebih penting daripada metode, dan jiwa guru lebih penting daripada guru itu sendiri (al-tariqah ahammu min al-maddah, al-mudarrisu ahammu min al-tariqah, wa ruh al-mudarrisi ahammu min al-mudarris). Karena itu, saat awal berdiri guru yang akan mengajar di Pesantren Nurussalam dilihat seberapa besar ruh jihad calon guru. Selain itu, di Pesantren Nurussalam masih ada sampai sekarang siswa yang tidak naik kelas. Karena masih menganut prinsip "ujian untuk belajar, bukan belajar untuk ujian" sebagaiamana yang dipraktekkan di PMDG. Salah satu muatan isi kurikulum PMDG yang masih diterapkan di Pesantren Nurussalam adalah materi didaktik dan metodik mengajar (ilmu keguruan) dengan menggunakan buku al-Tarbiyah wa al-Ta'lim. Seperti Gontor, di Pesantren Nurussalam terdapat bentuk pengabdian untuk mengamalkan ilmu di masyarakat. Bentuk pengabdian ini menjadi pra syarat bagi santri yang akan mendapatkan ijazah baik pendidikan formal MA atau pendidikan pesantren.

Orientasi "tidak berpartai" PMDG mewarnai orientasi pendidikan di Pesantren Nurussalam. Dalam beberapa kesempatan pihak pimpinan Pesantren Nurusslam menyatakan bahwa pesantrennya tidak ada hubungan dengan partai atau golongan tertentu. Menurut pimpinan pesantren, pondok ini sebagai lembaga pendidikan, dan demikian pula guru dan santrinya tidak boleh berpartai dan hraus senantiasa berdiri di atas dan untuk semua golongan. Bagi para santri, setelah mereka keluar dari pondok, mereka bebas memilih golongan, aliran, organisasi massa atau organisasi politik apa pun.

Hubugan Pesanten Nurussalam dengan Pesantren Al-Mukmin Ngruki terlihat pada sosok Ustadz Wahyudin sebagai pimpinan Pesantren Nurussalam sekaligus sebagai mudir pesantren Al-Mukmin Ngruki. Ustadz Wahyudin mengabdi di Pesantren Ngruki sejak tahun 1980-an. Awalnya, ia untuk belajar setelah dari Gontor. Lama kelamaan dirinya menjadi pengajar dan diangkat menantu oleh Abdullah Sungkar.

Ustadz Maksum Abdurahman dan Ustadz Yoyo Yahya merupakan alumni Pesantren Al-Mukmin Ngruki. Keduanya berbeda saat di Pesantren Ngruki. Ustadz Maksum Abdurahman di komunitas Pondok Ngruki Utara dan Ustadz Yoyo Yahya di komunitas Pondok Ngruki Selatan. Berikut adalah pola komunitas Pondok Selatan 
dan Utara Pesantren Ngruki serta tradisi yang dikembangkan. Polarisasi ini dikutip dari hasil penelitian Pesantren Ngruki oleh tim Puslitbang Pendidikan Agama dan Keagamaan pada tahun 2004.

Tabel 7: Komunitas Pondok Selatan dan Utara Pesantren Ngruki serta Tradisi yang Dikembangkan

\begin{tabular}{|c|c|}
\hline Pondok Selatan & Pondok Utara \\
\hline $\begin{array}{l}\text { Anggota kelompok KMI, KMA, } \\
\text { MTs kelas I, kelas Takhassus, } \\
\text { dan pengurus pondok (ustadz } \\
\text { muda) }\end{array}$ & $\begin{array}{l}\text { Anggota MTs.I, MAAM, } \\
\text { pengurus yayasan }\end{array}$ \\
\hline $\begin{array}{l}\text { Struktur sosial menempatkan } \\
\text { ustadz Abu Bakar Ba'asyir } \\
\text { sebagai pemimpin } \\
\text { kharismatik tetapi pada } \\
\text { peran keunggulan ilmu dan } \\
\text { kepribadian adalah guru } \\
\text { alumni KMI, Persis Bangil, } \\
\text { Timur Tengah khususnya guru } \\
\text { muda }\end{array}$ & $\begin{array}{l}\text { Struktur sosial menempatkan } \\
\text { ustadz Abu Bakar Ba'asyir } \\
\text { sebagai pemimpin } \\
\text { kharismatik tetapi pada } \\
\text { peran keunggulan ilmu dan } \\
\text { kepribadian tidak terbatas } \\
\text { pada guru alumni KMI, Persis } \\
\text { Bangil, Timur Tengah, tetapi } \\
\text { juga alumni PTU dan PTAI. }\end{array}$ \\
\hline $\begin{array}{l}\text { Orientasi Tafaqquh fiddin, } \\
\text { menjadi mujahid dakwah, } \\
\text { guru agama, mendirikan } \\
\text { pesantren }\end{array}$ & $\begin{array}{l}\text { Melanjutkan ke perguruan } \\
\text { tinggi agama dan perguruan } \\
\text { tinggi umum, berorientasi } \\
\text { sektor formal }\end{array}$ \\
\hline $\begin{array}{l}\text { Pemahaman keagamaan lebih } \\
\text { tektual, literal dan normatif. } \\
\text { Guru-guru alumni KMI, Persis, } \\
\text { Timteng menjadi pengawal } \\
\text { pemahaman keagamaan } \\
\text { mereka }\end{array}$ & $\begin{array}{l}\text { Pemahaman agama masih } \\
\text { tektual, tetapi membuka } \\
\text { penafsiran yang lebih longgar. } \\
\text { Guru-guru dari PTU dan } \\
\text { PTAIS menjadi pengewal } \\
\text { pemahaman keagamaan } \\
\text { mereka }\end{array}$ \\
\hline $\begin{array}{l}\text { Berpakaian lebih ketat } \\
\text { terhadap acuan normatif, } \\
\text { celana diatas kaki } \\
\text { mata kaki, berjenggot, } \\
\text { bersorban, mementingkan } \\
\text { kesederhanaan (kesadaran } \\
\text { normatif cukup tinggi). }\end{array}$ & $\begin{array}{l}\text { Terlihat dalam tradisi pakaian } \\
\text { relatif longgar bahkan tidak } \\
\text { jauh berbeda dengan siswa } \\
\text { di luar pondok (kesadaran } \\
\text { normatif rendah) }\end{array}$ \\
\hline $\begin{array}{l}\text { Pengasuh dan guru umumnya } \\
\text { alumni KMI, Persis Bangil, } \\
\text { Timur Tengah dan Gontor. }\end{array}$ & $\begin{array}{l}\text { Guru-guru banyak dari } \\
\text { tamatan perguruan tinggi } \\
\text { numum (UNS, UGM, IKIP, } \\
\text { UMS, dII), IAIN disamping } \\
\text { alumni KMI dan Timteng }\end{array}$ \\
\hline $\begin{array}{l}\text { Bahasa yang lazim } \\
\text { digunakan bahasa Arab } \\
\text { dan menganggapnya } \\
\text { sebagai bahasa Al-Quran. } \\
\text { Penggunaan bahasa }\end{array}$ & $\begin{array}{l}\text { Bahasa keseharian lebih } \\
\text { banyak menggunakan bahasa } \\
\text { Inggris; bahasa Arab lebih } \\
\text { dipahami sebagai bahasa } \\
\text { komunikasi, tidak memiliki } \\
\text { implikasi ideologis }\end{array}$ \\
\hline $\begin{array}{l}\text { Berorientasi kepada } \\
\text { pelayanan pendidikan dan } \\
\text { dakwah agama masyarakat } \\
\text { pedesaan }\end{array}$ & $\begin{array}{l}\text { Berorientasi kepada sektor } \\
\text { formal perkotaan }\end{array}$ \\
\hline
\end{tabular}

\begin{tabular}{|c|c|}
\hline $\begin{array}{l}\text { Alumninya mengajar, } \\
\text { mengasuh dan mendirikan } \\
\text { pesantren di berbagai daerah } \\
\text { (sektor pedesaan) }\end{array}$ & $\begin{array}{l}\text { Alumninya masuk sektor } \\
\text { formal, pegawai negeri, guru/ } \\
\text { dosen, pedagang, wiraswasta, } \\
\text { dsb (sektor perkotaan) }\end{array}$ \\
\hline $\begin{array}{l}\text { Muatan ideologi } \\
\text { lebih mengental dan } \\
\text { kecenderungan kepada } \\
\text { puritan/revivalisme }\end{array}$ & $\begin{array}{l}\text { Lebih terbuka, moderat } \\
\text { lebih menerima konsep } \\
\text { kebangsaan dan pluralitas } \\
\text { bangsa }\end{array}$ \\
\hline $\begin{array}{l}\text { Sebagian kegiatan } \\
\text { ekstrakulikuler bersifat } \\
\text { penguatan fisik serta } \\
\text { mengandung nuansa } \\
\text { militeristik (Sapala Kamufisa), } \\
\text { seni bela diri. }\end{array}$ & $\begin{array}{l}\text { Kegiatan ekstrakulikuler lebih } \\
\text { menonjol di bidang seni } \\
\text { budaya (az-Zukhruf) }\end{array}$ \\
\hline $\begin{array}{l}\text { Lingkungan pondok dipenuhi } \\
\text { dengan tulisan dan ornamen } \\
\text { semangat jihad, anti Yahudi/ } \\
\text { Amerika, pemihakan } \\
\text { terhadap Islam tertindas, } \\
\text { kritik terhadap pemerintah } \\
\text { (taghut), anti JIL. Solusi } \\
\text { terbaik adalah penegakan } \\
\text { syariat Islam. }\end{array}$ & $\begin{array}{l}\text { Kurang terlihat tulisan } \\
\text { dan ornamen tentang } \\
\text { jihad, kecuali kampannye } \\
\text { penguasaan bahasa Inggris } \\
\text { sebagai jembatan pergaulan } \\
\text { dunia, etika pergaulan } \\
\text { (pandangan terhadap } \\
\text { perempuan laksana panah } \\
\text { setan). }\end{array}$ \\
\hline
\end{tabular}

Dari dua kampus pondok Ngruki diatas, Tim Peneliti Puslitbang Pendidikan Agama dan Keagamaan Tahun 2004, menyatakan:

Terlihat perbedaan orientasi antara kelompok salafi haraki "fundamentalis" dengan mereka yang lebih moderat dalam kehidupan keseharian yang menghasilkan dua kutub budaya yang berbeda. Dalam perkembangan terlihat semakin menajam. Kelompok khittoh salafi semakin menunjukkan identitas kesalafihannya, termasuk kesiapan fisik mengantisipasi seruan "jihad fi sabilillah" menghadapi musuh-musuh umat Islam. Sebaliknya kelompok moderat berupaya meningkatkan kualitas pendidikan agar santrinya memiliki keunggulan kompetitif maupun komparatif, untuk masuk perguruan tinggi umum. Kasus tahun 1995 yang menyebabkan eksodusnya sejumlah santri dan ustadz merupakan akumulasi konflik atau pergumulan antara kelompok salafi haraki dengan kelompok moderat 
dalam rangka penentuan identitas Pondok Pesantren Ngruki. ${ }^{16}$

Meski demikian, Pesantren Ngruki saat ini tidak terlalu terlihat polarisasi antara komunitas Pondok Selatan dengan komunitas Pondok Utara. Bahkan menurut Murtadho dalam penelitiannya tahun 2016 menyatakan sistem Pendidikan di Pesantren Ngruki sudah terintegrasi antara sistem KMI dan MTS/MA. ${ }^{17}$

Berdasarkan pola komunitas Pondok Selatan dan Utara Pesantren Ngruki serta tradisi yang dikembangkan, ustadz Maksum Abdurahman yang berlatar belakang komunitas Pondok Ngruki Utara dan ustadz Yoyo Yahya yang berlatar belakang komunitas Pondok Ngruki Selatan ikut mewarnai orientasi pendidikan di Pesantren Nurussalam. Meskipun sama-sama memiliki orientasi tafaqquh fiddin, ustadz Yoyo Yahya banyak mewarnai tafaquh fiddin di Pesantren Nurussalam. Bahkan ia sendiri yang mengajar materi ushul fikih. Ia jugalah yang mengusulkan buku fikih organisasi Persatuan Islam menjadi buku rujukan kitab fikih di Pesantren Nurussalam.

Jika Maksum Abdurahman terlihat dalam tradisi pakaian relatif longgar bahkan tidak jauh berbeda dengan masyarakat Kujang yang memakai baju kemeja, sarung dan kopiah, maka ustadz Yoyo Yahya berpakaian lebih ketat terhadap acuan normatif, celana diatas kaki mata kaki,

${ }^{16}$ Fuaduddin TM, dkk. 2004. Pondok Pesantren Islam Al-Mukmin Ngruki Solo: Studi tentang Sistem Pendidikan, Faham Keagamaan dan Jaringan. Jakarta, Puslitbang Pendidikan Agama dan Keagamaan, h. 4

${ }^{17}$ Muhammad Murtadlo. 2016. Pesantren Al-Mukmin Ngruki Sukoharjo Pasca Bom Bali 2002. Puslitbang Pendidikan Agama dan Keagamaan Badan Litbang dan Diklat Kementerian Agama. berjenggot, bersorban, dan mementingkan kesederhanaan.

Ustadz Maksum Abdurahman baik dengan para santri maupun beberapa anggota masyarakat Kujang ikut bermain sepakbola futsal yang lokasi lapangannya tidak jauh dengan Pesantren Nurussalam. Sedangkan ustadz Yoyo Yahya sibuk melakukan dakwah-dakwah di berbagai daerah sekitar Tasikmalaya, Ciamis, dan Banjar. Abu Bakar Ba'asyir sebagai tokoh kharismatik membuat ustadz Yoyo Yahya mengikuti organisasi Jama'ah Anshorut Tauhid (JAT) sebagai ketua wilyah Jawa Barat, dan saat ini tercatat sebagai dewan syarian organisasi Jama'ah Anshorusy Syariah (JAS). Ustadz Yoyo Yahya mengisi kajian kitab hadist Arba'in an-Nawawi yang diselenggarakan setiap hari Minggu Kedua oleh JAS Mudiriyah Ciamis Perwakilan Majmu'ah Kota Banjar.

Salah satu lembaga pendidikan Islam yang berada dibawah naungan Kementerian Agama adalah madrasah. Lembaga madrasah memiliki sejarah panjang dalam konteks kelembagaan pendidikan Islam di Indonesia. Sejarah madrasah periode sebelum kemerdekaan adalah sejarah konsolidasi, institusionalisasi, dan penyebaran (dissemination). Periode selanjutnya, madrasah melakukan modernisasi lewat kebijakan Kementerian Agama. ${ }^{18}$

Selain faktor keinginan masyarakat untuk mendapatkan ijazah, modernisasi madrasah juga yang membuat ustadz Abdul Hadi membuka sistem madrasah berupa Madrasah Tsanawiyah (MTs) dan Madrasah

${ }^{18}$ Arief Subhan, 2012, Lembaga Pendidikan Islam Indonesia Abad ke-20: Pergumulan antara Modernisasi dan Identitas. Jakarta, Kencana, h. 211 
Aliyah (MA). Tahun 1993, Pesantren Nurussalam mengajukan kepada Kantor Kementerian Agama kabupaten Ciamis yang kemudian diajukan kepada Kantor Wilayah Kementerian Agama Provinsi Jawa Barat. Satu tahun berikutnya yaitu tahun 1994 keluar piagam pendirian madrasah melalui surat keputusan Kepala Kantor Wilayah Kementrian Agama Provinsi Jawa Barat tertanggal 19 Januari 1994.

Konsekuensi dari didirikan madrasah model Kementerian Agama adalah mengikuti peraturan-peraturan yang berlaku di Kementerian Agama dalam bidang pendidikan madrasah. Hubungan Pesantren Nurussalam dengan Pemerintah dalam hal ini Kementerian Agama semakin intens. Pesantren Nurussalam dituntut untuk memenuhi standarisasi nasional pendidikan dari mulai standar pendidik, standar peserta didik sampai standar kurikulum dan standar kelulusan. Bahkan kelembagaan madrasah dilakukan akreditasi.

Untuk menyediakan guru yang memenuhi kualifikasi dan kompetensi yang dipersyaratkan Kementerian Agama, pihak Pesantren Nurussalam melakukan kerjasama dengan beberapa pesantren seperti Pesantren Darussalam Ciamis. Ustadz Abdul Hadi pernah berguru kepada pimpinan Pesantren Darussalam, KH Irfan Hielmy. Melalui kontak dengannya, Ustadz Abdul Hadi berhasil meminta beberapa guru dari Pesantren Darussalam untuk mengajar di Pesantren Nurussalam. Selain itu, Pesantren Nurussalam dalam pengadaan guru menjalin hubungan dengan Pesantren Persis Kujang dan LIPIA. Untuk guru-guru mata pelajaran umum secara umum berasal dari Universitas Siliwangi Tasikmalaya,
Universitas Galuh Ciamis, dan Universitas Pendidikan Indonesia Bandung.

Sampai saat ini, Madrasah Tsanawiyah Nurussalam mendapat Bantuan Operasional Sekolah. Guru-guru MTs dan MA Nurussalam mengupayakan untuk tersertifikasi. Sudah beberapa guru MTs dan MA Nurussalam tersertifikasi oleh Kementerian Agama. Terkait dengan akreditasi nasional Sekolah/ Madrasah, Madrasah Aliyah Nurussalam dari tahun 2011 sampai tahun ajaran 2015/2016 memperoleh akreditasi dengan peringkat B (Baik) dari Badan Akreditasi Nasional Sekolah/Madrasah Provinsi Jawa Barat.

Intensitas hubungan Pesantren Nurussalam dengan Kementrian Aagama ditandai dengan adanya bantuan Ruang Kelas Baru (RKB) dari kemenag untuk 2 kelas pada tahun 2010. Kemenag juga pernah memberikan laboratorium untuk MA dan bantuan perpustakaan sebesar 35 juta untuk MTs.

Alumni Pesantren Nurussalam melanjutkan pendidikannya bervariasi. Ada yang melanjutkan ke Perguruan Tinggi baik negeri maupun swasta, ada yang mengabdi di masyarakat, dan ada yang menjadi pendidik di lembaga pendidikan yang diselenggarakan di masjid-masjid. Saat ini ada alumni Pesantren Nurussalam yang sedang belajar S2 di Universitas Al-Azhar Mesir. Salah satu putra pimpinan lembaga Misi Islam Jakarta yang merupakan alumni MTs Pesantren Nurussalam melanjutkan Madrasah Aliyahnya di Mesir. Sebanyak 4 alumni Pesantren Nurussalam sedang menempuh pelajaran di Madinah. 


\section{Pesantren Nurussalam dan Gerakan Salafi di Indonesia}

Perpecahan gerakan Salafi di Indonesia mempengaruhi model pendidikan yang dikembangkannya. Pesantren Bin Baz yang didirikan Abu Nida, misalnya, mendapat dukungan pembiayaan dari Jam'iyyah Ihya al-Turats al-Islami, sebuah organisasi sosial keagamaan yang bermarkas di Kuwait yang juga membuka kantor di Jakarta. Pesantren ini memiliki sarana dan prasarana yang lengkap. Kurikulumnya memadukan antara materi agama dan umum. ${ }^{19}$ Sebaliknya, pesantren Salafi yang dikembangkan Ja'far Umar Thalib dan jaringannya menolak seluruh materi non-agama dalam kurikulumnya. Sarana dan prasarananya sangat sederhana..$^{20}$ Noorhaidi Hasan melihat pesantren-pesantren Salafi tersebut berperan penting dalam akselerasi proses santrinisasi kelompok abangan. ${ }^{21}$ Abdul Aziz menyebut pesantren-pesantren Salafi itu sebagai pesantren yang memiliki karakter kontrakultur (counter culture).22

Nashir membagi beberapa corak atau orientasi Salafiyah yang berkembang di Indonesia. Pertama, "Salafiyah tradisional", yang berhimpitan dengan Ahlu as-Sunnah wa al-Jama'ah dan masih terikat dengan

19 Abdul Muin, dkk. 2007. Pendidikan Pesantren dan Potensi Radikalisme,Jakarta, Prasasti, h. 110-124.

${ }^{20} \mathrm{Abu}$ Mudjahid, 2012, Sejarah Salafi di Indonesia. Bandung, Toobagus Publishing, h. 196.

${ }^{21}$ Noorhaidi Hasan, 2008, “The Salafi Madrasas of Indonesia", dalam Farish A.Noor, Yoginder Sikand \& Martin van Bruinessen (eds), The Madrasa in Asia: Political Activism and Transnational Linkage, Amsterdam, ISIM Series on Contemporary Muslim Societies, Amsterdam University Press, h. 264.

${ }^{22}$ Lihat Kata Pengantar Abdul Aziz. 2011."Dari Subkultur Menuju Kontrakultur: Kontroversi AlZaytun sebagai Pesantren", dalam Tim Peneliti INSEP, Al-Zaytun: The Untold Stories, Jakarta, Pustaka Alvabet. paham mazhab Syafi'i, sebagaimana ditunjukkan oleh beberapa pesantren Salafiyah dan kelompok-kelompok tarekat. Kedua, "Salafiyah reformis" atau "Salafiyah modernis", yakni gerakan Islam yang ingin mengembalikan Islam kepada sumbernya yang asli (Al-Qur'an dan Sunnah Nabi), menolak bentuk-bentuk tradisi terutama yang bersifat syirik, tahayul, bid'ah, dan khurafat; serta yang lebih menonjol membawa tema dan gerakan pembaruan Islam (tajdid fi al-Islam) untuk bangkit dari kemunduran dan membangun perubahan ke arah kemajuan, serta tidak melibatkan diri dalam politik seperti Muhammadiyah, Al-Irsyad, Persatuan Islam. ketiga, "Salafiyah Dakwah" atau "Jamaah Salafiyah", yakni gerakan salafi yang lebih mengutamakan pemurnian akidah dan mempraktekkan cara hidup di zaman Nabi dan tiga generasi sesudahnya secaraketatdankeras, sertatidak melibatkan diri dalam kehidupan politik; sebagaimana ditampilkan oleh Salafiyah Yamani, Salafiyah Haraki, dan At-Turast. Keempat, "Salafiyah ideologis", yakni gerakan Islam yang mengusung pelembagaan syariat Islam secara formal dalam kehidupan umat Islam, termasuk dalam kehidupan negara dan membentuk Negara Islam dengan merujuk pada idealisasi kehidupan Islam zaman Nabi dan era kekhalifahan Islam di masa lampau untuk dipraktekkan di zaman sekarang sebagaimana ditunjukkan oleh MMI, HTI, KPPSI, dan kelompok Islam syariat lainnya yang serba harfiyah/legal formal, doktriner, dan militan. ${ }^{23}$

${ }^{23}$ Haedar Nashir, 2007, Gerakan Islam Syariat: Reproduksi Salafiyah Ideologis di Indonesia. Jakarta, Kencana. h. 144-145 
Orientasi Salafiyah yang ketiga dan yang keempat yakni Salafiyah Dakwah atau Jamaah Salafiyah dan salafiyah ideologis sebagaimana dipaparkan Nashir inilah yang diperinci oleh Abu Mujahid berdasarkan pengenalan masyarakat kepada pembagian Salafi menjadi kelompok Salafi Jihadi, kelompok Salafi Haraki, dan kelompok Salafi Yamani. $^{24}$

Pertama adalah kelompok yang sering dicap masyarakat sebagai Salafi Jihadi. Mereka dicap seperti ini karena komitmen masing-masing mereka untuk menentang pemerintah kaum muslimin yang telah mereka anggap menyimpang dari syariat Islam. Bagi mereka, syariat Islam harus didirikan lewat sebuah pemerintahan yang berkomitmen terhadap Islam. Sikap mereka seperti ini mereka yakini sebagai jihad, meski dalam bentuk memberontak kepada pemerintah.

Kedua adalah kelompok yang dicap masyarakat sebagai Salafi Haraki. Mereka terkenal karena sikap toleransi mereka terhadap (a) partai-partai politik dan (b) kelompok-kelompok juga tokoh-tokoh pergerakan Islam serta organisasi-organisasi filantropis seperti Ihya At-Turast, AshShafwah, dan Haramain.

Ketiga adalah kelompok yang disitilahkan masyarakat sebagai Salafi Yamani. Mereka dikenal dengan sebutan ini karena sikap keras kepala mereka untuk (a) tidak memberontak terhadap pemerintah kaum muslimin seburuk apa pun perlakuan pemerintah itu terhadap mereka, (b) tidak bergaul dengan partai-partai politik, kelompok-kelompok, tokoh-tokoh pergerakan Islam atau organisasi-organisasi

\footnotetext{
${ }^{24}$ Abu Mujahid., Op.Cit., h. 9-10
}

filantropis seperti Ihya' At-turash, AshShafwah, Al-Haramain, dan sejenisnya. Meski demikian banyak pula yang menyebut kelompok ketiga ini dengan sebutan seperti itu karena (c) banyak dai dan ustadz mereka yang belajar kepada syaikh-syaikh di Yaman.

Noorhaidi Hasan membagi salafi kepada Salafi Yamani dan Salafi Haraki atau Sururi. Salafi Yamani adalah pengikut Syek Muqbil di Yaman. Sedangkan salafi haraki atau sururi adalah pengikut Muhammad Surur bin Nayef Zainal Abidin. Ia adalah ulama Saudi Arabia yang mengkritik Pemerintah Saudi Arabia. Di Indonesia, Salafi Yamani diwakili Ja'far Umar Thalib, dan ia melabel saingannya sebagai kelompk sururi atau haraki. Menurut Noorhaidi, salafisme mendukung radikalisme. ${ }^{25}$

Din Wahid memetakan salafi kepada tiga, yakni: salafi purist, salafi haraki dan salafi jihadis. ${ }^{26}$ Pertama adalah salafi purist. Salafi purist terbagai tiga yaitu: rejectionis, cooperationist, dan tandzimi. Umumnya salafi purist adalah mereka berdakwah dan a- politis. Purist rejecsionis adalah kelompok salafi yang sama sekali tidak mau bekerjasama dengan ormas dan kelompok yang berbeda. Jika mereka memiliki pesantren, maka mereka menolak Sistem Pendidikan Nasional. Pelajaran umumnya hanya bahasa Indonesia dan Matematika. Yang termasuk salafi puris rejectionis diantaranya adalah Jafar Umar Thalib dan Pesantren Diyaussunah Cirebon. Mereka ini

${ }^{25}$ Noorhaidi Hasan, 2006, Laskar Jihad: Islam, Militansi dan Pencarian Identitas di Indonesia, Jakarta, LP3ES.

${ }^{26}$ Lihat Din Wahid, Bebarapa Catatan atas Laporan Penelitian Sistem Pendidikan, Paham Keagamaan dan Jaringan: Studi 20 Pesantren. Disampiakan dalam acara pra seminar 22 April 2016. 
oleh Noorhaidi Hasan dikategorikan Salafi Yamanis. Sedangkan Puris Cooperationis adalah mereka yang mau berkomunikasi dan sistem pendidikannya mengikuti kurikulum nasional. Mereka juga bisa bekerjasama dengan ormas Islam seperti Al-Irsyad, Muhamadiyah, dan Persis. Dapat disebut di sini sosok Abu Nida dengan pesantrennya. Adapun Puris Tandzimi adalah sama dengan rejectionist dan cooperationis, tetapi mereka mentransformasikan kepada ormas seperti Wahdah Islamiyah dan HASMI.

Kedua adalah Salafi Haraki. Termasuk kelompok ini adalah pondok pesantren Ngruki. Lembaga pendidikan yang dikelola pesantren mengadopsi sistem pendidikan nasional. Paham keagamaan mereka tersambung kepada genealogi ulama salafi. Relasi agama dan politik tidak terpisahkan. Mereka sering mengkritik pemerintah. Namun, Pesantren Ngruki saat ini berusaha untuk meminimalisir sosok Abu Bakar Ba'asyir. Ketiga adalah Salafi Jihadis. Kelompok ini bersifat eklektik (mengambil sana sini). Dalam kelompok ini bisa disebutkan seperti seperti Bali bombers. Terhadap salafi jihadis ini, Salafi Puris dan Salafi Haraki akan menolak prilaku tersebut.

Dari pembagian Salafiyah yang dilakukan Nashir, Salafi yang dipotret Abu Mujahid, Salafi yang dipolakan Noerhaidi Hasan, dan Salafi yang dipetakan Din Wahid, penulis mengadopsi kategori salafi yang dibuat Din Wahid. Sebagai alat analisis, kategorisasi Din Wahid dapat membaca dimana posisi Pesantren Nurussalam dalam konteks gerakan salafi di Indonesia.

Penulis mulai dari tokoh-tokoh pendiri Pesantren Nurussalam yaitu ustadz Abdul Hadi dan ustadz Wahyudin. Keduanya alumni Pondok Medern Gontor Ponorogo. Pesantren Gontor dikenal dengan semboyan berdiri diatas semua golongan. Karena alumni Gontor, tentu keduanya dipastikan mengadopsi sistem pendidikan Gontor. Selain alumni Gontor, ustadz Wahyudin juga mudir Pesantren Ngruki. Ustadz Maksum Abdurahman, wakil mudir Pesantren Nurussalam, selain alumni Pesantren Ngruki juga alumni LIPIA. Ustadz Yoyo Yahya, Sekretaris Pesantren Nurussalam, merupakan alumni Muhammadiyah dan Pesantren Ngruki.

Pesantren Nurussalam dilihat dari tradisi ketokohan pesantren memiliki warna tersendiri. Tidak ada figur sentral di Pesantren Nurussalam sehingga dalam pemahaman keagamaan tidak terpusat pada seorang tokoh kiai saja. Ustadz Wahyudin tidak langsung berkecimpung dalam penanganan pondok sehari-hari. Ustadz Maksum Abdurahman dan ustadz Yoyo Yahya yang sehari-hari menangani aktivitas pendidikan di Pesantren Nurussalam.

Ustadz Wahyudin sebagai mudir Pesantren Nurussalam dan ustadz Maksum Abdurahman dan ustadz Yoyo Yahya sebagai alumni Pesantren Ngruki tentu sedikit banyaknya diwarnai paham keagamaan Pesantren Ngruki. Pesantren Ngruki sesuai dengan garis khittahnya secara jelas mengidentifikasikan diri sebagai kelompok penerus cita-cita paham salafi yang ditambahkan di belakangnya dengan sebutan haraki. Paham salafi adalah paham berittitba atau mengikuti sunnah nabi, sahabat, tabiin dan tabiuttabiin yaitu sikap beragama yang hanya mendasarkan kepada al-Quran dan Hadis Sahih, menyatakan diri tidak bermazhab sekaligus menolak taklid dan mengakui pintu ijtihad tetap terbuka. 
Adapun tambahan haraki untuk menegaskan bahwa Pesantren Ngruki bergerak dalam bidang dakwah dan pendidikan. Konsekuensi tidak bermazhab dan pintu ijtihad tetap terbuka adalah tidak dibenarkan taklid di Pesantren Ngruki. ${ }^{27}$

Yoyo Yahya memandang salafi sebagai jamaah dakwah yang menyandarkan pola dakwahnya pada salaf yaitu pola Rasululllah dan para sahabat. Karena itu, nilai aqidah dan syariah tidak ada yang menyimpang dari ajaran Islam. Mereka berusaha untuk mengembalikan pada kemurnian Islam. "Islam secara kaffah" dalam tujuan yang hendak dicapai dari pendirian Pesantren Nurussalam dimaknai oleh komunitas Pesantren Nurussalam sebagai Islam yang bersandar kepada Al-Quran dan Hadits dengan jalan salaf. LIPIA yang dipengaruhi paham keagamaan Salaf-Wahabi tentu mempengaruhi paham keagamaan ustadz Maksum Abdurahman karena dirinya alumni LIPIA. Paham keagamaan LIPIA dicirikan dengan gerakan pemurnian (tashfiyah) dan pendidikan (tarbiyah).

Ustadz Yoyo Yahya saat ini menjadi salah satu pengurus dewan syariah Jama'ah Anshorus Syariah (JAS). Organisasi JAS adalah organisasi pecahan dari Jama'ah Anshorut Tauhid (JAT). JAS berdiri pada 11 Agustus 2014. Organisasi JAS dibentuk karena merespon kondisi perbedaan pendapat yang terjadi pada anggota JAT dalam menyikapi fenomena klaim Khilafah Islamiyah oleh ISIS. Amir JAT Abu Bakar Ba'asyir telah memutuskan bahwa seluruh

${ }^{27}$ LihatFuaduddin TM, dkk, 2004, PondokPesantren Islam Al-Mukmin Ngruki Solo: Studi tentang Sistem Pendidikan, Faham Keagamaan dan Jaringan. Jakarta, Puslitbang Pendidikan Agama dan Keagamaan, h. 9394. anggota JAT yang menolak klaim khilafah itu harus keluar dari jamaah dan tidak lagi berada dalam ikatan JAT.

\section{Radikalisme Keagamaan}

Apakah pesantren Nurussalam yang memiliki orientasi pendidikan salafi (baik pandangan maupun praktek) tersebut termasuk radikal. Pihak pesantren, dalam beberapa kesempatan wawancara dengan penulis, menolaknya. Mereka beralasan, pertama: mempertanyakan istilah "radikal". Bagi mereka, istilah "radikal" merupakan prototype yang digunakan Barat dan kemudian diikuti secara meluas di seluruh dunia untuk memberikan label terhadap penganut Islam yang konsisten. Menurut mereka ada citra negatif dalam kalimat "radikal". Kedua, apakah karena pesantren konsisten memperjuangkan nilai-nilai Islam yang didasarkan sematamata pada al-Quran dan Hadits (model salafi), lalu dituding sebagai Islam radikal atau ekstrim sebagaimana dialamatkan media masa kepada pesantren-pesantren. Terkait dengan hal ini, Yahya berkata:

yang kita bingungkan soal definisi kekerasan istilahnya teroris yang tidak jelas buat kami jadi ukurannya itu apa, ada yang bilang anak yang gak mau sholat dipukul itu dibilang kekerasan. Kalau definisi kekerasan tidak ada batasan kita juga jadi bingung. Menghukum santri karena melanggar dicepret dianggap kekerasan kita jadi bingung padahal itu baik buat anak. Pelajaraan hukuman masih dalam batas toleransi. Nah yang kita gak paham kekerasan gak ada definisinya jadi kabur, nyuruh anak dicepret itu kekerasan terhadap anak ini jadi bingung kalau gak ada batasan definisinya apa itu kekerasan? apa itu 
teroris? sebab sementara ini ya maaf-maaf saja pelaksana hukum di Indonesia itu tidak adil. ${ }^{28}$

Yahya mempertanyakan ketika ada orang Islam menganiaya orang non muslim disebut tindakan terorisme, tetapi ketika orang non muslim yang serupa seperti peristiwa di Papua dimana masjid dibakar, tetapi aktor intelektualnya dibiarkan dan dilepas karena orang Amerika bahkan pelakunya diundang ke istana, diajak makan, dan tidak dicap terorisme. Lebih lanjut Yahya mengatakan, Organisasi Papua Merdeka (OPM) seperti yang ada di internet banyak yang bawa senjata dan bendera OPM dan bendera bendera Israel, tidak disebut teroris. Dengan nada mempertanyakan, Yahya berkata:

Ini sebenarnya maunya apa, kalau bikin definisi untuk orang banyak bukan definisi karet, kepada orang Islam dicecer habis-habisan kita kan masyarakat kecil keadilan keadilan harus dirasakan semua masyarakat sebab undangundang hasil bikinan bersama, kita tidak setuju kalau pesantren dikatakan mendidik radikal, kekerasan dari sisi apa? kalaupun ada alumni yang setelah keluar bergabung dengan ini itu kita tidak bisa tanggung jawab sebab udah selesai tugasnya, sama dengan polisi yang jadi beking narkoba gak bisa lembaga yang disalahkan sebab lembaga sudah formal, sudah diakreditasi diakui berjalan dengan standar yang ada, adapun diluar itu bukan tanggung jawab instanti atau lembaga itu maunya sendiri dia berkomunikasi dengan orang yang mungkin ingin melakukan kekerasan, mungkin faktornya ketidakpuasan karena diperlakukan tidak adil terhadap Islam, akhirnya melakukan tindakan sendiri. Kita juga tidak setuju selama ada

${ }^{28}$ Wawancara dengan sekretaris pesantren, Yoyo Yahya, di kampus Pesantren Nurussalam, 7 dan 8 Pebruari 2016. celah selama ada jalur yang lain kenapa tidak ditempuh jalur yang ada. ${ }^{29}$

Tertuduhnya Pesantren Nurussalam dengan radikalisme agama menjadikan pesantren ini direspon dan datangi oleh berbagai kalangan. Salah satu wakil ketua MUI yang juga ketua PUI Ciamis dan ketua Forum Silaturahmi Pondok Pesantren Ciamis, Adiwan Juana, merespon Pesantren Nurussalam dengan menyatakan:

"setahu saya, Abu Bakar Ba'asyir dari Pesantren Ngruki. Awalnya sebelum ditangkap, ada orang yang membawa Abu Bakar Ba'asyir ke Pesantren Nurusslam. Namanya itu siapa, sampai saat itu dicari tidak ada orangnya. Kemudian Abdul Hadi sering diintrogasi di kantor polisi. Akhirnya sudah selesai, yang menyelesaikan juga MUI dan BKSPP. Selesai waktu itu. Abdul Hadi sudah meninggal. Awal penyelenggaraan semua siswanya ikut ujian di Persatuan Umat Islam (PUI). Sampaimendirikan sekolah sampai mengadakan ujian sendiri. Sebenarnya yang riil radikal itu di Cisaga yang keterlibatan ISIS. Dia mensponsori ISIS. Pesantren kecil itu bukan pesantren terkenal masih kalah jauh. Mau tidak mau karena Abu Bakar Ba'asyir diistirahatkan di sana ada yang membawa ke Nurussalam. Mungkin karena sama-sama dari Gontor. Yang membawa istirahatnya sedang dicari. Tidak tahu siapa. Sekarang lagi dicari sebetulnya. ${ }^{30}$

Adiwana Juana lebih lanjut mengatakan bahwa sampai saat ini dirinya tidak mengetahui keradikalannya, bahkan Nrussalam tidak ada unsur-unsur keradikalan. Menurutnya, itu orang media saja. Dirinya lama dengan bergaul dengan

29 Wawancara dengan sekretaris pesantren, Yoyo Yahya, di kampus Pesantren Nurussalam, 7 dan 8 Pebruari 2016.

${ }^{30}$ Wawancara dengan Adiwana Juana di Buniseuri Ciamis, pada 9 Februari 2016. 
Ustadz Abdul Hadi di MUI, FSPP dan FKUB. Adiwana Juana melihat Nurussalam menjadi korban. Masyarakat lingkungannya juga selama ini tidak ada apa-apa. Murid dan alumni Pesantren Nurussalam, menurutnya, tidak terdengar terlibat dalam organisasi. Juana melihat Pesantren Nurussalam itu milik yayasan bukan milik perorangan. Ia mengakui pernah mobil inventaris Pemda diberikan kepada Ustadz Abdul Hadi yang sama-sama di MUI dan FSPP, karena Ustadz Abdul Hadi tidak memiliki kendaraan. ${ }^{31}$

Ketika ditanya soal radikalisme Pesantren Nurussalam, Juana menolaknya karena selain sama-sama di ormas Islam, Ustadz Abdul Hadi dengan pesantrennya juga sekecamatan dengannya atau tetangga desa. Juana berpendapat Pesantren Nurusslam tidak terlihat paham wahabi, tetapi menonjol dalam bahasa Arab dan bahasa Inggris. Menurutnya bagaimana bisa disebut radikal, keponakan Juana juga bersekolah di Pesantren Nurussalam. Juana melihat diterimanya Abu Bakar Ba'asyir di Pesantren Nurussalam karena samasama alumni Pesantren Gontor, kemudian terbawa-bawa oleh permasalahan Abu Bakar Ba'asyir, dan itu yag dibaca orang. Namun suatu waktu, lanjut Juana, ustadz Abdul Hadi menolak untuk memasukan sekte-sekte Kristen di FKUB dan cenderung diwakili oleh satu orang saja dari GKI. ${ }^{32}$

Pihak Kemenag Kabupaten Ciamis lewat Kasi Pendidikan Diniyah dan Pondok Pesantren, Muhammad Aip Maftuh, menyatakan:

\footnotetext{
${ }^{31}$ Ibid.

${ }^{32}$ Ibid.
}

Adanya radikalisme pesantren karena berangkat dari ta'rif yang berbeda dan perbedaan kasih sayang. Kalau kita mengasihi pesantren itu karena pesantren adalah keluarga, anak. Sementara mereka posisinya tidak melihat sebagai anak. Anak bangsa, anak tetangga atau anak apa itu. tetapi mereka mereka sebagai obyek. Kalau diletakan sebagai obyek belaka, maka bisa diposisikan anak ayam atau anak kambing atau benda seperti bebatuan atau udara. Itulah perspektif kita. ${ }^{33}$

Lebih lanjut, Aip Maftuh, menyatakan Pondok Pesantren Nurussalam berdiri sejak tahun 1984. Pendirinya KH. Abdul Hadi dan KH. Wahyudin dengan mengambil corak pesantren modern (Khalafi) yang berafiliasi kepada model pesantren Gontor Ponorogo. Saat ini, sepeninggal KH. Abdul Hadi, Pondok Pesantren yang bersangkutan dipimpin oleh KH. Wahyudin, sedangkan pimpinan hariannya adalah Ustadz Ma'shum, dibantu oleh sejumlah ustadz dan ustadzah lainnya yang mengasuh sejumlah kurang lebih 420 orang santri yang berasal dari berbagai wilayah di sekitar Priangan, Jabodetabek, Banten, Sumatera, dan wilayah nusantara lainnya. Pondok Pesantren yang bersangkutan berada di bawah naungan Yayasan, yang di samping menyelenggarakan pendidikan Pesantren, juga pendidikan formal pra-sekolah (RA), Madrasah Tsanawiyah, dan Madrasah Aliyah. Kecuali murid RA, seluruh muridnya wajib mondok. Secara formal Pondok Pesantren

${ }^{33}$ Wawancara dengan Muhammad Aip Maftuh di rumah makan di Ciamis, 7 Februari 2016. Selama penelitian berlangsung pihak Pesantren Nurussalam sedang mengajukan pembaharuan izin pendirian pesantren kepada pihak Kementerian Agama Kabupaten Ciamis. Dan, beberapa bulan kemudian, Kementerian Agama Kabupaten Ciamis mengeluarkan izin pendirian Pesantren Nurussalam. 
Nurussalam Kujang belum memiliki Izin Operasional dan Nomor Statistik Pondok Pesantren, sehingga belum ada data dan identitasnya dalam EMIS maupun Direktori Pondok Pesantren versi Kementerian Agama. Adapun MTs dan MA telah mendapatkan izin operasional serta fasilitas sebagaimana mestinya seperti BOS, BSM, Bantuan Infrastruktur, Bantuan Sarana PBM dan sebagainya. Kemudian ia berpendapat bahwa Pondok Pesantren, termasuk Pondok Pesantren Nurussalam ini, sejatinya adalah lembaga pendidikan keagamaan Islam yang moderat; dan untuk mengembangkan nilai kemoderatannya diperlukan kehadiran negara yang lebih dekat, lebih tanggap dan lebih bijak. ${ }^{34}$

\section{PENUTUP}

Berdasarkan uraian di atas, penelitian ini menyimpulkan: pertama, sistem pendidikan Pesantren Nurussalam secara umum mengacu kepada sistem pendidikan nasional. Sistem pendidikan nasional yang diadopsi adalah sistem MTs dan MA ditambah dengan sistem pendidikan kepesantrenan yang diadopsi dari model Gontor dan model Ngruki. Tuntutan standarisasi pendidikan nasional tersebut sedang dan terus akan dipenuhi oleh pihak pesantren. Pihak pesantren menginginkan agar unit lembaga pendidikan terakreditasi dan gurunya tersertifikasi. Pendidik di pesantren berlatar belakang pendidikan pesantren AlIslam Ngruki dan Jaringan Ngruki, LIPIA, Darussalam Gontor dan model Gontor. Latar belakang organisasi para pendidik berasal dari: Persis, Muhammadiyah, dan

${ }^{34}$ Lihat hasil Survei Muhammad Ayip Maftuh ke Pesantren Nurussalam 5-6 Februari 2016
Sekretaris pesantren aktif di ormas Jamaah Anshorusyariah. Pesantren secara umum menggunakan kurikulum Kementerian Agama, Kurikulum Kemendikbud dalam unit pendidikan formal. Tetapi, dalam unit pendidikan kepesantrenan menggunakan kurikulum model Ngruki dan model Gontor. Dalam kurikulum bahasa, pesantren mengadopsi kurikulum Gontor.

Kedua, sistem pendidikan yang dibangun tersebut tidak lepas dari paham keagamaan para pendiri dan pengelolanya yang berpaham salafi, lebih tepatnya salafi puris cooperationis. Pada prinsipnya paham ini adalah paham berittitba atau mengikuti sunnah nabi, sahabat, tabiin dan tabiuttabiin, yaitu sikap beragama yang hanya mendasarkan kepada al-Quran dan Hadis Sahih, menyatakan diri tidak bermazhab sekaligus menolak taklid dan mengakui pintu ijtihad tetap terbuka. Karena muatan paham keagamaan tersebut, referensi syariah bersumber kepada kitabkitab yang digunakan aliran salafi. Dalam bidang fiqih (syariah) menggunakan kitab Minhajul Muslim karangan Abu Bakar Jabir Al-Jazairi. Ia tergolong ulama beraliran salafi yang tidak mendasarkan fiqhnya pada fiqih mazhab, tetapi langsung menggali sumbersumber rujukannya dari al-Quran dan Sunah. Dalam hal Aqidah akhlaq digunakan kitab Fathul Madjid/kitab Attauhid karya Syeikh Muhammad bin Abdul Wahhab dan kitab Tauhid karya Shalih bin Fauzan. Dalam hal tafsir, pihak pesantren menggunakan kitab ibnu katsir dan al-Maraghi, beberapa kasus menggunakan buku Al-Qur'an hadits dan tafsir yang digunakan Madrasah Aliyah Proram Khusus (MAPK) inisiasi Munawir Sadjali. Muatan paham keagamaan tersebut berpengaruh kepadajaringan yang dibangun 
yang nota bene berinteraksi dengan pesantren-pesantren yang bermutan paham yang sama seperti pesantren Ngruki (sebagai pusat jaringan pendidikan mereka), meski mengadopsi model pendidikan Gontor.

Ketiga, melihat bangunan pendidikan yang dipengaruhi oleh paham keagamaan model "salafi", Pesantren Nurussalam tidak bisa dikategorikan sebagai pesantren salafiyah sebagaimana pesantren-pesantren yang berideologi NU atau pesantren model Gontor dengan ideologi "modernnya". Karena itu Pesantren Nurussalam dengan paham keagamaan, muatan ideologi, rujukan literatur dalam proses pendidikannya memiliki kultur sendiri yaitu: "pendidikan salafi”. Jika model pendidikan tersebut dipraktekkan, maka diasumsikan beberapa pesantren sasaran sebagai kategori pesantren baru yaitu: Pesantren berbasis kultur salafi (salafi based-culture). Temuan ini memperkuat beberapa studi tentang eksistensi pesantren salafi, misalnya, Noerhaidi Hasan (2004) dan Din Wahid (2012).

Keempat, Pesantren Nurussalam menolak dikategorikan radikal. Mereka beralasan, pertama: mempertanyakan istilah "radikal". Bagi mereka, istilah "radikal" merupakan prototype yang digunakan Barat dan kemudian diikuti secara meluas di seluruh dunia untuk memberikan label terhadap penganut Islam yang konsisten. Menurut mereka ada citra negatif dalam kalimat "radikal". Kedua, apakah karena pesantren konsisten memperjuangkan nilainilai Islam yang didasarkan semata-mata pada al-Quran dan Hadits (model salafi), lalu dituding sebagai Islam radikal atau ekstrim sebagaimana dialamatkan media masa kepada pesantren-pesantren.
Kelima, secara institusional, Pesantren Nurussalam tidak terkait dengan gerakangerakan radikal yang bersifat "kekerasan" dalam memperjuangkan ideolgi salafinya. Pesantren tersebut tetap mengedepankan strategi dialogyang salah wujud kongkritnya berbentuk pendidikan berupa pesantren. Dengan demikian, pesantren tersebut untuk sementara ini adalah pesantren "salafi" yang tidak menggunakan karakter "kekerasan”. Mengapa Pesantren Nurussalam diindikasikan sebagai radikal? Dari data yang penulis peroleh terungkap bahwa: pimpinan pesantren memiliki hubungan kekerabatan dengan Abu Bakar Ba'asyir, salah satu tokohnya aktif dalam gerakan JAS, dan salah satu pendiri pernah aktif di Darul Islam (DI). Fakta-fakta tersebut yang barangkali menjadi indikator Pesantren Nurussalam dikategorikan sebagai pesantren radikal. Namun setelah tim peneliti melakukan konfirmasi, didapatkan bahwa fakta-fakta itu bisa terbantahkan. Pertama, Pimpinan Nurussalam tidak setuju dengan pendekatan dan perjuangan Abu Bakar Ba'asyir dan ISIS. Kedua, keterlibatan salah satu tokohnya di JAS dan JAS termasuk yang anti ISIS. Ketiga, salah satu tokoh pendiri yang dulunya aktif di DI sudah mengalami perubahan sesuai dengan realitas perkembangan zaman. Meski ada konfirmasi dari pihak pesantren, fakta "pernah ada" atau "ada hubungan kekerabatan" dengan kelompok dan gerakan radikal menjadi peluang bagi pesantren untuk mendapat akses dan potensi kepada kelompok atau gerakan radikal tersebut.

Rekomendasi penelitian adalah Kepada Pemerintah lebih banyak melakukan komunikasi dan pembinaan dengan Pesantren Nurussalam melalui penguatan standarisasi nasional pendidikan; penguatan 
kurikulum pendidikan kebangsaan (nasionalisme); bantuan sarana dan prasarana pendidikan termasuk sumber belajar seperti laboratorium IPA; perlakuan yang adil dalam pembiyaan pendidikan; dan inisiasi pertukaran tenaga pengajar antar pesantren.

Kepada Pesantren perlu meningkatan komunikasi yang intens dengan apatur pemerintah setempat, lebih kooperatif dan terbuka dengan Kemenag, berinisiasi menginformasikan bantuan sarana dan prasarana dari luar negeri kepada Kemenag setempat, dan mengikuti sistem pendidikan nasional.

\section{UCAPAN TERIMA KASIH}

Penelitian ini dibiayai anggaran Puslitbang Pendidikan Agama dan Keagamaan Badan Litbang dan Diklat Kementerian Agama RI. Peneliti mengucapkan terimakasih kepada Kepala Puslitbang Pendidikan Agama dan Keagamaan Dr. Hamdar Arraiyyah, M.Ag yang menugaskan peneliti dalam kegiatan penelitian Pesantren Nurussalam Ciamis. Penulis juga mengucapkan terimakasih kepada Ustadz Wahyudin sebagai mudir Pesantren Nurussalam yang memberikan izin kepada peneliti untuk melakukan penelitian tersebut. Ucapan terimakasih juga kepada ustadz Maksum dan ustadz Yahya yang turut membantu memfasilitasi pelaksanaannya penelitian ini. Ucapan terimakasih disampaikan kepada seluruh narasumber penelitian ini.

\section{DAFTAR PUSTAKA}

\section{Buku dan Jurnal}

Aziz, Abdul. (2011): "Dari Subkultur Menuju Kontrakultur: Kontroversi Al-Zaytun sebagai Pesantren", dalam Tim Peneliti INSEP, Al-Zaytun: The Untold Stories, Jakarta, Pustaka Alvabet.

Fuaduddin TM, dkk. (2004): Pondok Pesantren Islam Al-Mukmin Ngruki Solo: Studi tentang Sistem Pendidikan, Faham Keagamaan dan Jaringan. Jakarta, Puslitbang Pendidikan Agama dan Keagamaan.

Hasan, Noorhaidi. (2006): Laskar Jihad: Islam, Militansi dan Pencarian Identitas di Indonesia. Jakarta, LP3ES.

----, (2008): "The Salafi Madrasas of Indonesia", dalam Farish A.Noor, Yoginder Sikand \& Martin van Bruinessen (eds), The Madrasa in Asia: Political Activism and Transnational Linkage, Amsterdam, ISIM Series on Contemporary Muslim Societies, Amsterdam University Press.

Mudjahid, Abu. (2012): Sejarah Salafi di Indonesia. Bandung, Toobagus Publishing.

Mu'in, Abdul Muin, dkk. (2007): Pendidikan Pesantren dan Potensi Radikalisme. Jakarta, Prasasti.

Nashir, Haedar. (2007): Gerakan Islam Syariat: Reproduksi Salafiyah Ideologis di Indonesia. Jakarta, Kencana.

Subhan, Arief. (2012): Lembaga Pendidikan Islam Indonesia Abad ke-20: Pergumulan antara Modernisasi dan Identitas. Jakarta, Kencana

Zarkasyi, Abdullah Syukri. (2005): Gontor dan Pembaharuan Pendidikan Islam, Jakarta, PT Raja Grafindo Persada. 
-----, (2005): Manajemen Pesantren: Pengalaman Pondok Modern Gontor, Jawa Timur, Trimurti Press

\section{Dokumen}

Bebarapa Catatan atas Laporan Penelitian Sistem Pendidikan, Paham Keagamaan dan Jaringan: Studi 20 Pesantren. Disampaikan oleh Din Wahid dalam acara pra seminar 22 April 2016.

Daftar Pesantren Yang Terindikasi Berafiliasi dengan kelompok Radikal HasilProfiling Badan Nasional Penanggulangan Terorisme (BNPT) Tahun 2014.

Daftar siswa MTs dan MA Nurussalam Tahun Pelajaran 2015-2016.

Dokumen Sejarah Singkat Pendirian Pondok Pesantren Nurussalam yang dikeluarkan Pesantren Nurussalam.

Hasil Survei ke Pesantren Nurussalam 5-6 Februari 2016 oleh Muhammad Ayip Maftuh.

Lembaga Pondok Pesantren Umum Kabupaten Ciamis Tahun Pelajaran 2015-2016, Kasi Pondok Pesantren Kementerian Agama Ciamis

Murtadlo, Muhammad. 2016. Pesantren AlMukmin Ngruki Sukoharjo Pasca Bom Bali 2002. Puslitbang Pendidikan Agama dan Keagamaan Badan Litbang dan Diklat Kementerian Agama.

Salinan Akta pendirian yayasan Nurrusalam tanggal 17 Desember 2015 Nomor 409.

\section{Koran dan Majalah}

Kompas, Kamis 2 Januari 2014.

Republika, 3/2/2016.

Republika, 4/2/2016.

Tempo, Selasa 10 Agustus 2010.

\section{Wawancara}

Wawancara dengan wakil mudir pesantren, Maksum Abdullah, di kampus Pesantren Nurussalam, 7, 8 Pebruari 2016 dan 25 Maret 2016.

Wawancara dengan sekretaris pesantren, Yoyo Yahya, di kampus Pesantren Nurussalam, 7 dan 8 Pebruari 2016.

Wawancara dengan Andi, putra almarhum ustadz Abdul Hadi, di Kemenag Ciamis pada 24 Maret 2016.

Wawancara dengan Kasi Kemenag Ciamis, Muhammad Aip Maftuh, di Kantor Kemenag Ciamis, 28 Maret 2016.

Wawancara dengan Adiwana Juana, Wakil Ketua MUI Ciamis di Buniseuri Ciamis, pada 9 Februari 2016. 